\title{
The Influence of Work Culture and Work Commitment to Teacher Professionalism of Vocational High School
}

\author{
Rahmawati $^{1 *}$, Happy Fitria ${ }^{2}$, Rohana ${ }^{2}$
}

\author{
${ }^{1}$ SMK Negeri 3 Sekayu \\ ${ }^{2}$ Universitas PGRI Palembang \\ *Corresponding author. Email: yantiy03@gmail.com
}

\begin{abstract}
This study was carried out in the Sekayu District of State Vocational High School teachers with several goals as: (1) Is there an effect of work culture on teacher professionalism in vocational high school in Sekayu districts; (2) Is there an effect of work dedication on teacher professionalism in vocational high school in Sekayu districts; (3) Is there an influence of work culture and work commitment together on the professionalism of vocational teachers in Sekayu districts. This analysis was carried out using quantitative techniques and data were collected by administering questionnaires to 110 vocational high school teachers in districts of Sekayu. In addition, the data obtained were validated using the Predictive Product and Service Solution (SPSS). The findings of this study suggest that: (1) there is an impact of work culture on the professionalism of teachers at vocational high school in Sekayu districts by 48 percent with an at-count of 9.993 and a t-table of 1.9822, (2) there is an effect of teacher work contribution to work culture in vocational high school in Sekayu districts is 36 percent with an at-count value of 7.729 and a t-table, (3) Job culture and teacher work engagement combined have an effect on teacher professionalism in Sekayu districts at vocational high school of 52 percent with a value of 58,615 and a value table of 3.08. The conclusion of this study is that a work culture and work dedication is needed in improving the professionalism of teachers in SMK vocational high school in Sekayu districts.
\end{abstract}

Keywords: Work Culture, Work Commitment, Teacher Professionalism.

\section{INTRODUCTION}

In the age of globalization, which is full of problems like today, preparation is one way to improve and reinforce the standard of human capital. It is very well known that education is important for any individual since education is very important for the growth and continuation of the life of the country. The standard of education is the product of an appraisal of the educational process with high targets to be accomplished, by efforts to improve the potential of educational clients through the process. The tutor is one of the human tools to optimize human efficiency.

In the field of schooling, teachers are the major players, in particular, formal education in schools. The teacher is also the one who, particularly in the teaching and learning process decides the progress or failure of students. According to the PP RI [1], Article 20 (a) about teachers and lecturers, the professional duties of teachers are to organize instruction, to carry out a quality learning process, and to assess and evaluate learning outcomes. A type of teacher professionalism is the primary duty of the teacher, which is manifested in learning practices as well as the duties of teachers in institutions.

Teacher professionalism is a synergistic aspect that must be established to produce competent educators capable of delivering an instructional method that is important to the requirements of the graduate consumer community's situation, circumstances, and needs. A great deal of teacher professionalism is related to the poor standard of education [2].

According to the Permendiknas [3], academic qualification levels and teacher skills, namely: 1 . Mastering the topic being taught, structure, principles and scientific mentality that promotes the subject; 2 . Mastering levels of competency and specific competencies in the area of subject/development being handled; 3. Developing tools for artistic learning; 4. Sustainably improve professionalism by taking reflective action; 5. To connect and establish themselves using information and communication technologies. 
Teacher practitioners are often influenced by the variables of teacher work atmosphere and task engagement. The work culture of teachers is essentially the principles that become a person's behaviors in deciding the quality of work. In carrying out their mandate, the profession they hold, their sense of moral obligation, the job community of teachers can be seen by their sense of responsibility [4].

In order to optimize the opportunity for insight and time, an instructor is required. Nevertheless, in a classroom, of course, educators are expected to be able to have the best results according to their skills at their school. In addition to expertise, job dedication is often required for lecturers, instructors, staff, or workers to give the best results. For people and associations working together to accomplish educational objectives, school organizations are comprised of diverse components. The teacher is an individual being who has an important role in evaluating the performance of an instructional process, without bias to other aspects of the school organization. Regulation of the Minister of Education and Culture Number 67 of 2013 is concerning the Basic Framework and Structure of the Primary School/Madrasah [3].

\section{METHODS}

\section{Types of Research}

A quantitative method of an ex post facto the analysis methodology is the method used in this research. There are independent variables $X_{1}$ and $X_{2}$ in this analysis respectively works culture and work engagement. Then, teacher professionalism is the dependent variable (Y). In this analysis, the outcome or consequence is teacher professionalism, then job culture and teacher involvement is the trigger, resulting in good or poor teacher professionalism.

\section{Research Subjects and Data}

Teachers at vocational teachers in Sekayu districts were the test subjects. The population in this study was all teachers who worked in Sekayu District public vocational high schools, namely SMKN 1, SMKN 2, and SMKN 3 Sekayu, totaling 152 persons, the number of samples used in this study was calculated based on the Slovin system using the Slovin formula, then the number of teachers is 110 .

To determine the impact of teacher pedagogical competence and professional competence on teacher performance, research data was obtained using questionnaires and documentation studies. The tools used were to evaluate the effectiveness of the implementation of Augmented Reality-based learning media in increasing students' interest and learning outcomes in a science subject. The findings revealed variations in the interests of students in studying science before and after, based on the data collected. The posttest was conducted in experimental and control groups to assess the increase in the interest of each student and the outcomes of learning science, while Augmented Reality-based media was not used in the learning process in the control group. In each group, the post-test was conducted after the procedure was completed.

\section{RESULTS AND DISCUSSION}

The summary of the data provided by the findings of this analysis is intended to provide a general description of the distribution of data collected in the field using the instrument and documentation distribution. The study data consisted of three variables, namely job culture data $\left(\mathrm{X}_{1}\right)$, work dedication $\left(\mathrm{X}_{2}\right)$, and professionalism of teachers (Y), which were collected through the implementation of the SPSS version 26 software program from the data processing results.

\subsection{Descriptive Statistical Analysis}

The frequency distribution of data from the variables of teacher professionalism, work culture and work commitment is as follows:

Table 1 Descriptive Statistical Analysis Results

\begin{tabular}{|l|c|c|c|c|}
\hline \multicolumn{2}{|l|}{} & $\begin{array}{l}\text { Culture } \\
\text { (X1) }\end{array}$ & $\begin{array}{l}\text { Commitme } \\
\text { nt (X2) }\end{array}$ & $\begin{array}{c}\text { Professionalism } \\
(Y)\end{array}$ \\
\hline \multirow{2}{*}{$\mathrm{N}$} & Valid & 110 & 110 & 110 \\
\cline { 2 - 5 } & Missing & 0 & 0 & 0 \\
\hline \multicolumn{2}{|l|}{ Mean } & 74.67 & 31.00 & 67.55 \\
\hline Median & 77.50 & 31.00 & 68.50 \\
\hline Mode & 82 & 40 & 80 \\
\hline Std. Deviation & 8.748 & 6.166 & 10.021 \\
\hline Skewness & -.619 & -.033 & -.523 \\
\hline Std. Error Skew & .230 & .230 & .230 \\
\hline Kurtosis & -.699 & -.807 & -.413 \\
\hline Std. Error Kurt & .457 & .457 & .457 \\
\hline Minimum & 54 & 14 & 41 \\
\hline Maximum & 89 & 40 & 80 \\
\hline
\end{tabular}

Data on work culture, namely the lowest score of 54 and the highest score of 89 , the average count (mean) 74.67 , the middle value (median) 77.50, mode 82 , and standard deviation 8.748 were derived from the respondents' responses to the findings of descriptive statistical analysis. The results of the above calculations show that the value of skewness is -0.619 and the value of kurtosis is -0.699 and that the value of skewness and kurtosis is between -2 and +2 from these statistics, so it can be said that the distribution of the sample data is usual for the values of the work community [5].

The lowest score is 14 and the highest score is 40 , the average count (mean) is 31.00 , the middle value (median) is 31.00 , the mode 40 , and the standard deviation is 6.166 for teacher job engagement. The 
findings of the above calculations show that the skewness value is -0.033 and the kurtosis value is -0.807 and that the skewness and kurtosis value of both data is in the range between -2 and +2 , so it can be said that the distribution of the sample data on the work commitment value is natural [5].

For the teacher professionalism results in Table 1 above, the lowest score is 41 and the highest score is 80 , the mean (mean) is 67.55, the mean (median) is 68.50, the model is 80 , and the standard deviation is 10.021 . The results of the above calculations show that the value of skewness is -0.523 and the value of kurtosis is -0.413 and that the value of skewness and kurtosis is in the range between -2 and +2 from these statistics, so it can be said that the distribution of the pedagogical competence value sample data is natural $[6,7]$.

\subsection{Testing Data Analysis Requirements}

\section{a. Normality Test}

The data normality test was conducted using the Kolmogorov Smirnov test (K-S test) with a meaningful $5 \%$ or $\alpha=0.055$ standard (in Sudjana, 2010: 280). If the significant level (Asym. Sig) is about 0.05, it can be said that data is normally distributed.

Conversely, if the significant quantity (Asym. Sig) is $<0.05$, the data is said not to be naturally distributed. It is possible to summarize the outcomes of measuring the normality of work culture variables $\left(\mathrm{X}_{1}\right)$ and work contribution $\left(\mathrm{X}_{2}\right)$ to instructor professionalism $(\mathrm{Y})$ as follows:

a. Data from the work culture $\left(X_{1}\right)$ has a meaningful value of $0.080<0.05$, so the data is typically transmitted.

b. Job interaction data $\left(X_{2}\right)$ has a substantial value of $0.150<0.05$, so the data is usually transmitted.

c. Data on instructor professionalism (Y) has a meaningful value of $0.065<0.05$, so knowledge is typically transmitted.

\section{b. Linearity Test}

In this case, the variable of the work culture has a linear or non-linear relationship with the variable of teacher professionalism and the variable of the task culture has a linear or no relationship with the variable of teacher professionalism.

Results of measurements via the program framework SPSS version 26 are obtained:

1. There is a large value on the linearity line of 0.094 for the outcomes of the linearity measure for the variable job atmosphere and teacher professionalism. The linearity importance value of $0.094 \geq \alpha(\alpha=0.05)$ based on the linearity test criterion indicates that the association between work culture and teacher discipline is linear.

2. In linearity 0.098 , the outcomes of the linearity evaluation for vector task engagement and teacher, professionalism has an important significance. The significant value of linearity from the ANOVA table is over $0.098 \geqslant a(\alpha=0.05)$ based on the linearity measure criterion, so the relationship between job dedication and instructor professionalism is linear.

\section{c. Multicolinearity Test}

The multicollinearity test results from the results of the implementation of the software program SPSS version 26 show that each variable has a tolerance value $>0.10$ and a VIF value $<10.00$, so it can be inferred that there is no multicollinearity in the regression of this model between the variables of job community, work participation, and teacher professional.

The findings of the research study by SPSS version 26 fulfilled the criteria for further analysis, namely partial and simultaneous hypothesis testing analysis between the variables tested using multiple linear regression analysis, from the results of the normality test, linearity test, and multicollinearity test above.

\subsection{Hypothesis Test}

\section{a. Multiple Linear Regression Coefficient Analysis}

From the results of multiple linear regression analysis through the SPSS version 26 software program, the following results were obtained:

Tabel 2. Linear Regression Coefficient Analysis

\begin{tabular}{|c|c|c|c|c|c|}
\hline \multicolumn{6}{|c|}{ Coefficients $^{\mathrm{a}}$} \\
\hline \multirow{2}{*}{ Model } & \multicolumn{2}{|c|}{$\begin{array}{l}\text { Unstandardized } \\
\text { Coefficients }\end{array}$} & \multirow{2}{*}{\begin{tabular}{|c|}
$\begin{array}{l}\text { Standardized } \\
\text { Coefficients }\end{array}$ \\
Beta
\end{tabular}} & \multirow{2}{*}{\multicolumn{2}{|c|}{ t Sig. }} \\
\hline & B & $\begin{array}{l}\text { Std. } \\
\text { Error }\end{array}$ & & & \\
\hline (Constant) & 9.208 & 5.759 & & 1.599 & 113 \\
\hline Culture (X1) & .602 & .099 & .526 & 6.114 & 000 \\
\hline $\begin{array}{l}\text { Commitment } \\
\text { (X2) }\end{array}$ & .431 & .140 & .265 & 3.084 & 003. \\
\hline
\end{tabular}

From the table above, the constant coefficient (constant) $=9.208$, the coefficient $X_{1}=0.602$ and the coefficient $\mathrm{X}_{2}=0.431$ are derived in such a manner that the multiple linear regression equation is obtained:

$$
\begin{aligned}
& Y=a+b_{1} X_{1}+b_{2} X_{2} \\
& Y=9,208+0,602 X_{1}+0,431 X_{2}
\end{aligned}
$$

Note:

Y : Teacher Professionalism 


$$
\begin{aligned}
& \mathrm{X}_{1} \text { : Work Culture } \\
& \mathrm{X}_{2} \text { : Work Commitment }
\end{aligned}
$$

\section{b. Coefficient Determination Analysis}

To determine the value of the correlation between the independent variable $(\mathrm{X})$ consisting of Work Culture $\left(\mathrm{X}_{1}\right)$ and Work Commitment $\left(\mathrm{X}_{2}\right)$ based on the dependent variable (Y), namely Teacher Professionalism, the coefficient of determination $\left(R_{2}\right)$ is used.

The following results were obtained from the results of multiple linear regression analysis through the SPSS version 26 software program:

Tabel 3. Variable Determination Coefficient of $X_{1}$ and $\mathrm{X}_{2}$ Simultaneously against $\mathrm{Y}$

\begin{tabular}{c|c|c|c|c|c|}
\hline \multicolumn{4}{c|}{ ANOVA $^{\mathbf{a}}$} \\
Model & $\begin{array}{c}\text { Sum } \\
\text { of Squares }\end{array}$ & $\begin{array}{c}\text { Mean } \\
\text { Square }\end{array}$ & Sig. \\
\hline $\begin{array}{c}\text { Regressi } \\
\text { on }\end{array}$ & 5722.249 & 2861.124 & 8.6 & $.000^{\mathrm{b}}$ \\
\hline Residual & 5222.924 & 07 & 48.812 & & \\
\hline Total & 10945.173 & 09 & & & \\
\hline
\end{tabular}

The $\mathrm{R}$ Square value is 0.523 in Table 3 , so the determination coefficient is 52 percent, so it can be concluded that teacher professionalism is affected by work culture $\left(\mathrm{X}_{1}\right)$ and work engagement $\left(\mathrm{X}_{2}\right)$, the remaining $52 \%$ is affected by other variables that are not included in these two variables.

\section{c. Partial Linear Regression Analysis (t-Test)}

The results of partial linear regression analysis ( $\mathrm{t}-$ test) on the variables of Work Culture $\left(\mathrm{X}_{1}\right)$, and work commitment $\left(\mathrm{X}_{2}\right)$ to the dependent variable $(\mathrm{Y})$, namely the professionalism of teachers using the SPSS version 26 software program are shown below:

1. A significant value of $0.000<5 \%$, so Ho is rejected, which means that the variable of work culture $\left(\mathrm{X}_{1}\right)$ has a statistically significant and significant effect on the teacher's professionalism at $5 \%$. (Y). The value of $\mathrm{t}$-count is 9.993 and the value of the t-table is 1.9822 so that tcount > table is rejected, so Ho is rejected, which means that the work culture variable $\left(\mathrm{X}_{1}\right)$ has a statistically significant and significant effect on the teacher professionalism variable at $\alpha 5 \%(\mathrm{Y})$.

2. A significant value of $0.000<5 \%$, then Ho is rejected, which means that the variable of work commitment $\left(\mathrm{X}_{2}\right)$ has a statistically significant and important effect on the variable of teacher professionalism at $5 \%(\mathrm{Y})$. The value of the t-count is 7,729 and the value of the t-table is 1.9822 , so tcount $>$ table means that $\mathrm{Ho}$ is rejected, the variable of work commitment $\left(\mathrm{X}_{2}\right)$ has an impact and is statistically significant at $5 \%$ on the variable of teacher professionalism (Y).

\section{d. Simultaneous Multiple Regression Analysis}

This test is used to determine whether the coefficient of regression has a significant effect on the dependent variable or not simultaneously (together) between the independent variables $\left(\mathrm{X}_{1}\right.$ and $\left.\mathrm{X}_{2}\right)(\mathrm{Y})$. If Sig. $\geq(0.05)$, then the coefficient of regression is not significant. Sig. If Sig. $<\alpha(0.05)$, then the coefficient of regression is significant. Multiple linear regression analysis, which is shown in Table 4, is often referred to as concurrent hypothesis testing or f-test. The results of calculations using the software program SPSS version 26 are below.

Table 4. Simultaneous Multiple Linear Regression Analysis Results (f-Test)

\begin{tabular}{|c|c|cc|c|}
\hline \multicolumn{5}{|c|}{ Model Summary } \\
Model & $\mathrm{R}$ & $\begin{array}{c}\mathrm{R} \\
\text { Square }\end{array}$ & $\begin{array}{c}\text { Adjusted } \\
\text { R Square }\end{array}$ & $\begin{array}{l}\text { Std. Error } \\
\text { of the } \\
\text { Estimate }\end{array}$ \\
\hline 1 & $.723^{\mathrm{a}}$ & .523 & .514 & 6.987 \\
\hline $\begin{array}{l}\text { a. Predictors: (Constant), Commitment (X2), } \\
\text { Culture (X1) }\end{array}$ \\
\hline
\end{tabular}

The significance value for the effect on teacher professionalism (Y) at the same time as work culture $\left(\mathrm{X}_{1}\right)$ and work commitment $\left(\mathrm{X}_{2}\right)$ is $0.000<0.05$ and the $\mathrm{F}$ value is $58.615>\mathrm{F}$ table 3.08 , so it can be concluded that there is a significant cultural influence. Work $\left(\mathrm{X}_{1}\right)$ and work commitment $\left(\mathrm{X}_{2}\right)$ in conjunction with the professionalism of teachers $(\mathrm{Y})$.

\subsection{Discussion}

a. The Influence of Work Culture on Teacher Professionalism in Vocational High School in Sekayu Districts.

There is an impact of work culture $\left(\mathrm{X}_{1}\right)$ on teacher professionalism (Y) based on the results of data analysis, this is in line with Noor [8], work culture in an organization (school) has 5 (five) principles, namely : 1) Integrity, staff with good personal integrity are people who are always consistent in their words and deeds; 2) Integrity, working for the best outcomes in a disciplined and prompt way that are qualified, trustworthy and responsible in carrying out their profession; 3) Creativity produces fresh and improved things; 4) Accountability functions thoroughly and consequently; 5) Outstanding ensures that workers become positive 
models for others, arising from behavioral behaviors shared by others.

In addition to this culture of work, teachers must have extensive knowledge, master different types of learning materials, master the theory and practice of education and master the curriculum and methodology of learning. However, every teacher must be good at getting along with the community as a member of society. For this purpose, he must learn social science, know about interpersonal relationships, have abilities for group forming, abilities for coordination, and complete assignments in groups together. Teachers must have a style that represents an educator, as people interested in education and even as members of society. Teachers can therefore be interpreted as individuals whose responsibilities relate to efforts to teach the life of the nation in all aspects, both spiritual and emotional, intellectual, physical, and other aspects $[9,10]$.

\section{b. The Influence of Work Commitment on Teacher Professionalism in Vocational High School in Sekayu Districts.}

In line with the findings of study, entitled The Impact of Job Inspiration, Coordination, and Dedication on the Professionalism of Junior High School Science Teachers in Rayon Sabatu, Parigi Moutong Regency, there is an effect of work commitment $\left(\mathrm{X}_{2}\right)$ on teacher professionalism (Y), based on the results of data analysis (Case Studies on Rayon Sausu, Balinggi, and Torue). The outcomes revealed that: (1) The contribution of teachers to the professionalism of junior high school teachers of science in Rayon Sabatu, Parigi Moutong Regency, (2) has a major impact on the professionalism of junior high school teachers of science in Rayon Sabatu, Parigi Moutong Regency, (3). In Sabatu District, Parigi Moutong Regency, a major partnership between job inspiration and work devotion to the professionalism of junior high school science teachers.

\section{c. The Influence of Work Culture and Work Commitment on Teacher Professionalism}

The effect of job culture $\left(\mathrm{X}_{1}\right)$ and task engagement $\left(\mathrm{X}_{2}\right)$ on teacher professionalism is focused on the effects of data analysis (Y). Professionalism for Elementary School Teachers in North Lampung Regency, Abung Tinggi City. The findings have shown that corporate culture, dedication and desire for success has an impact on professionalism. If someone is highly motivated and wishes to attain good results, the partnership must be facilitated by human and corporate variables to enhance performance. Effective results can yield incentives that come both from inside the person and from beyond the person. The intrinsic reward will influence motivation, the extrinsic reward will induce pleasure and will improve motivation in turn. This is in line with Rovasi [12] view that culture will increase participation and enhance the continuity of organizational members' actions. Therefore, instructor participation is a dimension that affects the culture of organizations.

\section{CONCLUSION}

Based on data interpretation, hypothesis testing, and discussion of the definitions previously presented, it can be concluded that: (1) with a t-count of 9.993 and a table value of 1.9822, there is an effect of work culture on the professionalism of teachers of State Vocational Schools in Sekayu District by 48 percent; (2) there is a $36 \%$ impact of job dedication on the professionalism of State Vocational High School teachers in Sekayu District with a t-count of 7.729 and at a table of 1.9822 , (3) there is an impact of work culture and work commitment together on teacher professionalism SMK Negeri in Sekayu District is 52 percent with an f-count value of 58.615 and a value of 3.08. The conclusion of this research is that a working culture and job dedication are required to improve the professionalism of teachers in SMK Negeri Sekayu District.

\section{REFERENCES}

[1] Peraturan Pemerintah Republik Indonesia (PP RI) No 19 tahun 2005 Tentang Sistem Pendidikan Nasional. Jakarta.

[2] Irby, B. J., Brown, G., Duffy, J. A., \& Trautman, D. (2002). The synergistic leadership theory. Journal of Educational Administration.

[3] Peraturan Menteri Pendidikan Nasional (Permendiknas) No. 16 tahun 2007, Standar Kualifikasi Akademik dan Kompetensi Guru. Jakarta.

[4] Reis-Jorge, J. (2007). Teachers' conceptions of teacher-research and self-perceptions as enquiring practitioners-A longitudinal case study. Teaching and Teacher Education, 23(4), 402-417.

[5] Kesumawati, N., \& Aridanu, I. (2018). Statistik Parametrik. Palembang. Noerfikri Offset.

[6] Demirkasımoğlu, N. (2010). Defining “Teacher Professionalism" from different perspectives. Procedia-Social and Behavioral Sciences, 9, 2047 2051.

[7] Whitty, G. (2000). Teacher professionalism in new times. Journal of in-service education, 26(2), 281295.

[8] Noor, M., Makhsun, N. (2017). Kompetensi dan Budaya Kerja Guru dalam Membentuk Proferionalisme Guru Madrasah Ibtidaiyah di 
Kabupaten Temanggung. Universitas PGRI Semarang.

[9] Day, C. (2004). A passion for teaching. Psychology Press.

[10] Lindholm, J. A., \& Astin, H. S. (2008). Spirituality and pedagogy: Faculty's spirituality and use of student-centered approaches to undergraduate teaching. The Review of Higher Education, 31(2), 185-207.

[12] Ravasi, D., \& Schultz, M. (2006). Responding to organizational identity threats: Exploring the role of organizational culture. Academy of management journal, 49(3), 433-458. 